\title{
Hematological and biochemical responses of pirarucu (Arapaima gigas, Arapaimidae) fed with diets containing a glucomannan product derived from yeast and algae
}

\author{
Maria Danielle Figueiredo Guimarães HOSHINO ${ }^{1,2,3 *}$; Renata das Graças Barbosa MARINHO ${ }^{3,4}$; Diogle \\ Farias PEREIRA ${ }^{2,3}$, Eliane Tie Oba YOSHIOKA ${ }^{1,3}$; Marcos TAVARES-DIAS ${ }^{1,3}$; Rodrigo Otavio de Almeida \\ OZORIO $^{5,6}$; Anselmo Fortunato Ruiz RODRIGUEZ ${ }^{7}$; Ricardo Amaral RIBEIRO ; Fernando Sérgio Escócio \\ Drummond Viana de FARIA ${ }^{7}$

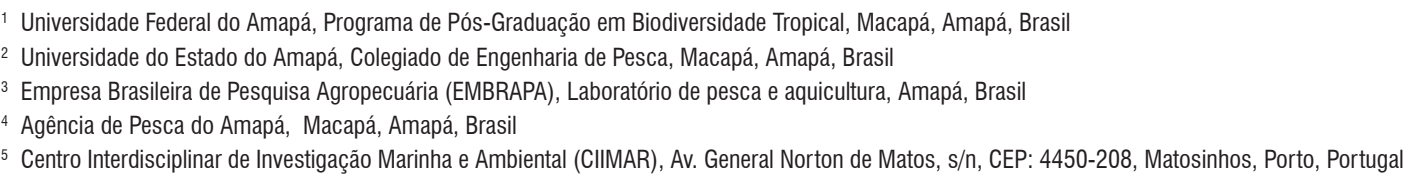

\section{ABSTRACT}

The hematological and biochemical responses of pirarucu fingerlings (Arapaima gigas) fed with diets containing different concentrations of a glucomannan product derived from yeast and algae were evaluated in order to ascertain the effect of these diets on fish physiology. Four treatments were conducted, with three replications, with 12 fish in each tank. The product evaluated $\left(\mathrm{MycosorbA+}^{\oplus}\right)$ was incorporated into the commercial diet, at four concentrations: $0,1,2$ and $4 \mathrm{~g} . \mathrm{kg}^{-1}$, called $\mathrm{M} 0 \%$, $\mathrm{M} 0.1 \%, \mathrm{M} 0.2 \%$ and M0.4\%, respectively. After 45 days of feeding, blood samples from six fish in each replicate were collected to perform the analyses. Their weight and length were determined to calculate the condition factor and weight gain, but no differences $(P>0.05)$ were observed among the treatments. No changes to the hematocrit, hemoglobin or erythrocyte levels or to the hematimetric indices of the pirarucus were observed. The glucose and triglyceride levels of the pirarucus in the M0.1\% and $\mathrm{M} 0.2 \%$ groups were significantly lower than those of the M0\% group. The M0.2\% group showed higher albumin levels $(\mathrm{P}<0.05)$ than $\mathrm{M} 0 \%$ and $\mathrm{M} 0.4 \%$. The M0.4\% group showed a total cholesterol level that was significantly higher than in all other treatments. MycosorbA ${ }^{\circ}$ contributed towards increasing the levels of defense cells in A. gigas. It would be possible to use this product at concentrations of between $0.1 \%$ and $0.2 \%$, given that they increase the levels of some defense cells and plasma albumin concentrations, without changes to hematological parameters, cholesterol and triglyceride plasma levels or condition factor.

KEYWORDS: Chlorella vulgaris, Saccharomyces cerevisiae, leukocytes, albumin.

\section{Respostas hematológicas e bioquímicas de pirarucu (Arapaima gigas, Arapaimidae) alimentado com dietas contendo mananoligossacarídeos derivados de leveduras e algas}

\section{RESUMO}

As características hematológicas e bioquímicas de alevinos de pirarucu Arapaima gigas alimentados com diferentes concentraçóes de mananoligossacarídeos derivados de leveduras e algas na dieta foram avaliadas para verificar o efeito sobre sua fisiologia. Quatro tratamentos foram conduzidos com três repetiçóes (12 peixes em cada). O produto avaliado (MycosorbA+ $\left.{ }^{\circledR}\right)$ foi incorporado à ração comercial, em quatro níveis: $0,1,2$ e $4 \mathrm{~g} \mathrm{~kg}^{-1}$ de raçáo, denominados $\mathrm{M} 0 \%, \mathrm{M} 0,1 \%$, M0,2\% e M0,4\%, respectivamente. Após 45 dias de alimentaçáo, amostras de sangue de seis peixes de cada repetição foram coletadas para realização das análises. O peso e comprimento foram obtidos para cálculo do fator de condição e ganho de peso, entretanto, não foram observadas diferenças $(\mathrm{P}>0,05)$ entre os tratamentos. Assim como não foram observadas alteraçóes nos valores de hematócrito, hemoglobina, eritrócitos e índices hematimétricos dos pirarucus. A concentração de glicose e triglicérides dos pirarucus dos grupos M0,1\% e M0,2\% foram significativamente menores que o tratamento $\mathrm{M} 0 \%$. Os peixes do tratamento M0,2\% apresentaram níveis de albumina maior $(\mathrm{P}<0,05)$ que do $\mathrm{M} 0 \%$ e M0,4\%. Os peixes alimentados com M0,4\% mostraram nível de colesterol total significativamente maior que todos os demais tratamentos. MycosorbA $+{ }^{\oplus}$ contribuiu para o aumento das células de defesa de A. gigas, podendo ser utilizado nas concentraçóes de $0,1 \%$ a $0,2 \%$, devido ao aumento do número de certas células de defesa e dos níveis plasmáticos de albumina e por não ter sido observadas outras alteraçóes nos parâmetros hematológicos, nos níveis plasmáticos de colesterol e triglicérides e no fator de condição.

PALAVRAS-CHAVE: Chlorella vulgaris, Saccharomyces cerevisae, leucócitos, albumina. 


\section{INTRODUCTION}

The Brazilian national production of pirarucu (Arapaima gigas Schinz 1822) in 2014 was approximately 11.7 tons (IBGE 2015). The potential for successful farming of this species lies in its growth performance, in which a weight of $10 \mathrm{~kg}$ can be reached within the first year of life (SEBRAE 2011). Although pirarucu is a carnivorous fish, it can accept dry feed and can tolerate the stress of high stocking densities and handling (Cavero et al. 2004; Brandão et al. 2006; SEBRAE 2011). Pirarucu is widely accepted in the market (Araújo et al. 2009).

In intensive farming systems, fish are always subjected to high levels of stress (Roriz et al. 2015) and are susceptible to many diseases (Bairwa et al. 2012), that can lead to significant changes to fish physiology (hematological and biochemical) (Cristea et al. 2012). Moreover, adequate nutrition programs are essential for avoiding signs of deficiency and diseases among aquatic organisms and thus maintaining their health and satisfactory normal growth performance (Chagas et al. 2009; Oliva-Teles 2012).

However, the quality of the fish food and care in administering it are essential factors for successful production. If these factors are neglected, mycotoxin production may be promoted. Mycotoxins are natural secondary metabolites produced by molds and fungi (Murjani, 2003; Di Gregorio et al. 2014), which may cause disease and death among humans and other animals (Bennett and Klich 2003). The effects on health may include carcinogenic effects, kidney damage, gastrointestinal disorders or suppression of the immune system (Murjani 2003; Selim et al. 2014; Karthikeyan et al. 2015; Anater et al. 2016). The major effects of mycotoxins on fish include reduced survival, growth, weight gain, erythrocyte and leukocyte counts, plasma total protein levels and blood hemoglobin concentration. Furthermore, these effects may involve hematocrit changes, increased ALT, AST and ALP enzyme levels and increased plasma albumin levels (Anater et al. 2016).

The mycotoxin adsorption process occurs through the carbohydrate components of yeast (Saccharomyces cerevisiae) and algae (Chlorella vulgaris). Cell walls and hydrated aluminosilicates bind to mycotoxins, thus removing them from the fish's digestive tract. Moreover, S. cerevisiae can also be used as a growth promoter and immunostimulant in some fish species (Siwicki et al. 1994; Sakai 1999; Selim et al. 2014). There is some evidence for the economical importance of protection from mycotoxins using adsorbents, although very few studies have tested these substances in aquaculture (Selim et al. 2014).

Glucomannan is a water-soluble polysaccharide that is a component of cell walls. It may be isolated and used as a potential protection promoter against mycotoxins in animal husbandry. The aim of the present study was to evaluate the hematological, biochemical and physiological characteristics of pirarucu (A. gigas) fingerlings that were fed with different concentrations of a product containing glucomannan that was derived from yeast and algae, to ascertain its effects on fish health.

\section{MATERIALS AND METHODS}

\section{Experimental diets}

The trade name of the product tested in this study is MycosorbA+ ${ }^{\oplus}$. According to its manufacturer (Alltech ${ }^{\oplus}$ Biotechnologies; Alltech do Brasil Agroindustrial Ltda., Araucária, Paraná, Brazil), it reduces mycotoxin absorption in animals and contributes towards controlling the damaging effects of mycotoxins on their health. The product MycosorbA $+{ }^{\circledast}$ is a supplement for animals, in the form of flour consisting of dried beer yeast, sodium and calcium aluminosilicate and the algae Chlorella vulgaris, according to the manufacturer's technical specification. The manufacturer's general recommendation for use of the product among animals, including for aquaculture, is that 0.5 to $2 \mathrm{~kg}$ of product per ton of feed should be used.

In the present study, MycosorbA+ ${ }^{\oplus}$ was supplemented into commercial extruded feed for carnivorous fish, at three levels (or treatments): $1.0 \mathrm{~g}$ in $1.0 \mathrm{~kg}$ of feed, called M0.1\%; $2.0 \mathrm{~g}$ in $1.0 \mathrm{~kg}$ of feed, called M0.2\%; and $4.0 \mathrm{~g}$ in $1.0 \mathrm{~kg}$ of feed, called $\mathrm{M} 0.4 \%$. In addition, a control diet consisting of the commercial diet without supplementation was used and was called $\mathrm{M} 0 \%$. The approximate chemical composition of the commercial diet and the product tested, in terms of crude protein, lipids (ether extract), dry matter and ashes, is indicated in Table 1. Analyses were performed in triplicate, in accordance with the guidelines of the Association of Official Analytical Chemists (AOAC 1995).

Table 1. Proximate chemical composition (\%) on fresh basis (mean and standard deviation) of commercial diet and Mycosorb ${ }^{\circledR} \mathrm{A}+$.

\begin{tabular}{lcccc}
\hline & Crude protein & Ether extract & Dry matter & Ashes \\
\hline Commercial diet & $48.55 \pm 5.82$ & $3.61 \pm 0.56$ & $90.61 \pm 0.07$ & $14.33 \pm 0.10$ \\
Mycosorb ${ }^{\circledR}$ A+ & $32.04 \pm 0.22$ & $0.03 \pm 0.01$ & $94.23 \pm 0.05$ & $19.67 \pm 0.10$ \\
\hline
\end{tabular}




\section{Experimental design}

Pirarucu fingerlings were acquired from a commercial fish farm (in Rio Branco, state of Acre, Brazil) and were transported to the Aquaculture and Fisheries Laboratory, Embrapa Amapá (in Macapá, state of Amapá, Brazil). They were acclimated to the laboratory conditions for 20 days in tanks of 1,000 L of water with aeration and continuous water flow. During this period, the fish were fed ad libitum four times a day with commercial extruded feed for carnivores containing $45 \%$ crude protein (CP) (Nutripiscis AL 45E, Presence, Evialis do Brasil Nutrição Animal Ltda., Paulínia, São Paulo, Brazil). These experiments were carried out under authorization nr. 08/2014 from the Ethics Committee for Animal Use (CEUA) of the Federal University of Acre (UFAC).

Four treatments comprising addition of MycosorbA+ ${ }^{\circ}$ to the experimental diet were performed, in a completely randomized design. Each treatment had three replicates (experimental tanks), with 36 fish per treatment, and 12 fish per tank (mean fish weight of $88.2 \pm 5.1 \mathrm{~g}$ and mean fish length of $22.9 \pm 0.4 \mathrm{~cm}$ ). The fish were fed with the experimental diets four times a day (at 8:00, 10:00, 14:00 and 16:00), comprising $10 \%$ of their biomass, for 45 days. After the feeding period, the fish were weighed and their body weight $(\mathrm{g})$ and length $(\mathrm{cm})$ were used to calculate the relative condition factor (Kn) (Le-Cren 1951). The dissolved oxygen levels, temperature and $\mathrm{pH}$ of the water were measured daily using a multiparameter probe (Horiba, model U52; Kyoto, Japan), in order to obtain physical and chemical variables relating to the water, throughout the experimental period.

\section{Hematological-biochemical analysis}

Blood samples from six fish in each experimental tank (18 fish per treatment) were collected by caudal vessel puncture, with sodium heparin as an anticoagulant. Each blood sample was used to determine hematocrit level $(\mathrm{Ht})$, hemoglobin concentration $(\mathrm{Hb})$ and red blood cell count (RBC). Mean corpuscular volume (MCV), mean corpuscular hemoglobin $(\mathrm{MCH})$ and mean corpuscular hemoglobin concentration (MCHC) were calculated, as described by Ranzani-Paiva et al. (2013). The leukocyte respiratory activity (respiratory burst) was determined in accordance with Sahoo et al. (2005) and Biller-Takahashi et al. (2013), with absorbance readings from a spectrophotometer (Biospectro SP-220; Curitiba, Paraná, Brazil). Total leucocyte and thrombocyte counts and differential leucocyte counts were made using blood smears stained with May-Grünwald-Giemsa-Wright, by means of an indirect method (Ishikawa et al. 2008; Ranzani-Paiva et al. 2013).

The remaining blood samples were centrifuged at $13,709 \mathrm{~g}$ for 5 min (Centrifuge 5424, Eppendorf, Hamburg, Germany) and the plasma was separated out. The plasma was used to determine the concentrations of glucose, protein, albumin, cholesterol and triglycerides, using colorimetric kits (Labtest Diagnóstica S.A., Lagoa Santa, Minas Gerais, Brazil) that were specific for each of the metabolites, with absorbance readings from a spectrophotometer (Biospectro SP-220; Curitiba, Paraná, Brazil).

\section{Statistical analysis}

The results were subjected to the Kolmogorov-Smirnov normality test and the Bartlett homoscedasticity test. They were then compared using analysis of variance (ANOVA), and statistical differences between groups were investigated using parametric or nonparametric tests. Differences were considered significant at 5\% probability (Zar 2010).

\section{RESULTS}

The water quality parameters did not show any differences at any time during the experiment (Table 2 ) and they remained within the tolerable limits for the maintenance and health of the fish. After 45 days of feeding, the weight, length and condition factor of the pirarucus in the experimental groups did not show any significant differences $(P>0.05)$ among treatments (Table 3).

The different concentrations of MycosorbA ${ }^{\circ}$ tested did not promote any changes in $\mathrm{Ht}, \mathrm{Hb}, \mathrm{RBC}, \mathrm{MCV}, \mathrm{MCH}$ or $\mathrm{MCHC}$ (Table 4). Inclusion of $0.1 \%$ MycosorbA+ ${ }^{\circ}$ in the diet promoted a higher circulating thrombocyte count in the pirarucus $(\mathrm{P}<0.05)$, in relation to those that received $0.2 \%$ and the control group. The leukocyte respiratory activity of the pirarucus did not show any difference among the treatments. The total leukocyte count was lower in the pirarucus fed with a diet containing $0.2 \%$ MycosorbA $+^{\circ}$, in relation to all the other groups. The lymphocyte, monocyte, neutrophil, LG-PAS and eosinophil counts did not show any statistically significant differences $(\mathrm{P}>0.05)$. The group fed with $0.2 \%$ MycosorbA+ ${ }^{\circ}$ showed a lower basophil count $(\mathrm{P}<0.05)$ in relation to the group M0.4\% (Table 4).

The plasma glucose concentration of the pirarucus in the control group was significantly higher than all the other treatments, and there were significant differences between $0.1 \%$ and $0.2 \%$ and between $0.1 \%$ and $0.4 \%$ (Table 5). The fish in the group $\mathrm{M} 0.4 \%$ had significantly higher plasma protein levels $(\mathrm{P}<0.01)$ than those in $\mathrm{M} 0.1 \%$. The fish in the group $\mathrm{M} 0.2 \%$ had significantly higher albumin levels ( $\mathrm{P}$ $<0.05)$ than those in $\mathrm{M} 0 \%$ and $\mathrm{M} 0.4 \%$. The triglyceride concentration was significantly higher in $\mathrm{M} 0 \%$ than in all the other treatments, and there was also a significant difference between M0.2\% and M0.4\%. Fish fed with $0.4 \% \mathrm{MycosorbA+}^{\circledR}$ showed total cholesterol levels that were significantly higher than in all other treatments; and there was also a significant difference between $\mathrm{M} 0 \%$ and $\mathrm{M} 0.1 \%$. 
Table 2. Physical and chemical variables (mean and standard deviation) of water from the experimental tanks in which the Arapaima gigas fingerlings were kept and fed with diets containing different concentrations of Mycosorb ${ }^{\circledR} \mathrm{A}+(\mathrm{M} 0 \%, \mathrm{M} 0.1 \%, \mathrm{M} 0.2 \%$, and $\mathrm{M} 0.4 \%)$.

\begin{tabular}{lcccc}
\hline & M0\% & M0.1\% & M0.2\% & M0.4\% \\
\hline $\mathrm{pH}$ & $5.19 \pm 0.1$ & $5.31 \pm 0.1$ & $5.24 \pm 0.0$ & $5.22 \pm 0.0$ \\
Dissolved oxygen $\left(\mathrm{mg} \mathrm{L}^{-1}\right)$ & $7.02 \pm 0.6$ & $6.42 \pm 0.2$ & $6.69 \pm 0.0$ & $6.67 \pm 0.1$ \\
Temperature $\left({ }^{\circ} \mathrm{C}\right)$ & $29.40 \pm 0.4$ & $29.55 \pm 0.6$ & $29.9 \pm 0.2$ & $29.9 \pm 0.2$ \\
\hline
\end{tabular}

Table 3. Body weight (initial and final), weight gain, body length and condition factor (Kn) (mean \pm standard deviation) of Arapaima gigas fingerlings fed with diets containing different concentrations of Mycosorb ${ }^{\circledR} \mathrm{A}+(\mathrm{M} 0 \%, \mathrm{M} 0.1 \%, \mathrm{M} 0.2 \%$, and $\mathrm{M} 0.4 \%)$.

\begin{tabular}{lcccc}
\hline & M0\% & M0.1\% & M0.2\% & M0.4\% \\
\hline Initial weight $(\mathrm{g})$ & $88.2 \pm 4.4$ & $87.8 \pm 5.2$ & $89.5 \pm 5.1$ & $87.4 \pm 4.5$ \\
Final weight $(\mathrm{g})$ & $235.7 \pm 94.8$ & $235.8 \pm 66.6$ & $234.6 \pm 66.2$ & $232.7 \pm 72.8$ \\
Weight gain $(\mathrm{g})$ & $147.5 \pm 91,0$ & $147.9 \pm 64,3$ & $145.1 \pm 64,6$ & $145.3 \pm 70,9$ \\
Length $(\mathrm{cm})$ & $33.8 \pm 3.1$ & $35.1 \pm 2.4$ & $35.1 \pm 2.5$ & $34.4 \pm 3.1$ \\
Kn & $0.99 \pm 0.01$ & $1.00 \pm 0.03$ & $0.999 \pm 0.02$ & $1.00 \pm 0.02$ \\
\hline
\end{tabular}

Table 4. Hemogram parameters of Arapaima gigas fingerlings fed with diets with different concentrations of Mycosorb ${ }^{\mathrm{A}} \mathrm{A}+(\mathrm{M} 0 \%$, M0.1\%, M0.2\%, and M0.4\%): hematocrit (Ht), hemoglobin concentration ( $\mathrm{Hb}$ ), erythrocyte count (RBC), mean corpuscular volume (MCV), mean corpuscular hemoglobin (MCH) mean corpuscular hemoglobin concentration (MCHC), respiratory activity of leukocytes (Burst) and number of thrombocytes and leukocytes (total and differential counts) (mean \pm standard deviation). Upper case letters indicate statistically significant differences between levels of inclusion.

\begin{tabular}{|c|c|c|c|c|}
\hline & $\mathrm{M} 0 \%$ & $\mathrm{M} 0.1 \%$ & $\mathrm{M} 0.2 \%$ & M0.4\% \\
\hline $\mathrm{Ht}(\%)$ & $25.5 \pm 5.9^{a}$ & $26.5 \pm 4.8^{\mathrm{a}}$ & $26.9 \pm 3.9^{a}$ & $25.1 \pm 6.8^{\text {a }}$ \\
\hline $\mathrm{Hb}\left(\mathrm{g} \mathrm{dL}^{-1}\right)$ & $11.8 \pm 2.5^{a}$ & $11.7 \pm 2.4^{\mathrm{a}}$ & $12.6 \pm 1.9 \mathrm{a}$ & $12.5 \pm 2.9$ a \\
\hline $\operatorname{RBC}\left(x 10^{6} \mu \mathrm{L}^{-1}\right)$ & $1.0 \pm 0.3^{a}$ & $1.1 \pm 0.4^{\mathrm{a}}$ & $1.0 \pm 0.4^{a}$ & $0.9 \pm 0.4^{a}$ \\
\hline MCV (fL) & $227.6 \pm 62.9^{a}$ & $260.3 \pm 77.6^{a}$ & $256.7 \pm 91.4^{a}$ & $257.3 \pm 32.6^{a}$ \\
\hline $\mathrm{MCH}\left(\mathrm{g} \mathrm{dL}^{-1}\right)$ & $108.2 \pm 31.1^{\mathrm{a}}$ & $113.5 \pm 32.8^{a}$ & $147.6 \pm 78.2^{a}$ & $118.9 \pm 26.9^{a}$ \\
\hline $\mathrm{MCHC}\left(\mathrm{g} \mathrm{dL}^{-1}\right)$ & $47.1 \pm 4.1^{\mathrm{a}}$ & $44.1 \pm 3.4^{\mathrm{a}}$ & $47.3 \pm 6.6^{a}$ & $47.9 \pm 4.1^{\text {a }}$ \\
\hline Burst (OD $540 \mathrm{~nm}$ ) & $0.40 \pm 0.0^{a}$ & $0.47 \pm 0.1^{\mathrm{a}}$ & $0.46 \pm 0.0^{a}$ & $0.46 \pm 0.0^{a}$ \\
\hline Thrombocytes $\left(\times 10^{3} \mu \mathrm{L}^{-1}\right)$ & $6.5 \pm 5.8^{b}$ & $18.2 \pm 8.4 \mathrm{ac}$ & $8.3 \pm 4.7^{b}$ & $10.9 \pm 4.5^{b c}$ \\
\hline Leukocytes $\left(\times 10^{3} \mu \mathrm{L}^{-1}\right)$ & $54.1 \pm 13.0$ ac & $34.0 \pm 13.9 \mathrm{ac}$ & $28.8 \pm 17.6^{b}$ & $52.5 \pm 14.9$ a \\
\hline Lymphocytes $\left(x 10^{3} \mu \mathrm{L}^{-1}\right)$ & $46.6 \pm 10.0^{a}$ & $28.2 \pm 14.1^{\mathrm{a}}$ & $25.4 \pm 16.5^{a}$ & $43.4 \pm 14.7^{a}$ \\
\hline Monocytes $\left(\times 10^{3} \mu \mathrm{L}^{-1}\right)$ & $1.9 \pm 2.2^{a}$ & $3.1 \pm 1.0^{a}$ & $1.8 \pm 1.3^{a}$ & $3.4 \pm 2.7^{\mathrm{a}}$ \\
\hline Neutrophils $\left(x 10^{3} \mu \mathrm{L}^{-1}\right)$ & $3.4 \pm 2.3^{a}$ & $1.8 \pm 1.0^{a}$ & $1.0 \pm 0.5^{a}$ & $3.9 \pm 3.0^{a}$ \\
\hline LG-PAS $\left(\times 10^{3} \mu \mathrm{L}^{-1}\right)$ & $0.17 \pm 0.3^{a}$ & $0.83 \pm 0.8^{a}$ & $0.52 \pm 0.6^{a}$ & $1.0 \pm 2.0^{a}$ \\
\hline Eosinophils $\left(x 10^{3} \mu \mathrm{L}^{-1}\right)$ & $0^{\text {a }}$ & $0.05 \pm 0.1^{\mathrm{a}}$ & $0^{a}$ & $0.15 \pm 0.2^{\mathrm{a}}$ \\
\hline Basophils $\left(\times 10^{3} \mu \mathrm{L}^{-1}\right)$ & $2.0 \pm 2.4 a b$ & $0.10 \pm 0.1 \mathrm{ab}$ & $0.01 \pm 0.0^{b}$ & $0.75 \pm 0.7^{\text {a }}$ \\
\hline
\end{tabular}

Table 5. Glucose, protein, albumin, triglycerides and cholesterol plasma concentrations (mean and standard deviation) of Arapaima gigas fingerlings fed diets with different concentrations of Mycosorb ${ }^{\circledR} \mathrm{A}+(\mathrm{M} 0 \%, \mathrm{M} 0.1 \%, \mathrm{M} 0.2 \%$, and $\mathrm{M} 0.4 \%)$. Upper case letters indicate statistically significant differences between levels of inclusion.

\begin{tabular}{lcccc}
\hline & M0\% & M0.1\% & M0.2\% & M0.4\% \\
\hline Glucose $\left(\mathrm{mg} \mathrm{dL}^{-1}\right)$ & $36.57 \pm 9.0^{\mathrm{a}}$ & $11.66 \pm 2.1^{\mathrm{b}}$ & $23.64 \pm 6.4^{\mathrm{c}}$ & $21.08 \pm 5.9^{\mathrm{d}}$ \\
Protein $\left(\mathrm{g} \mathrm{dL}^{-1}\right)$ & $3.00 \pm 1.0^{\mathrm{ab}}$ & $2.66 \pm 1.3^{\mathrm{b}}$ & $3.81 \pm 0.8^{\mathrm{ab}}$ & $4.05 \pm 1.4^{\mathrm{a}}$ \\
Albumin $\left(\mathrm{g} \mathrm{dL}^{-1}\right)$ & $0.97 \pm 0.2^{\mathrm{b}}$ & $1.15 \pm 0.3^{\mathrm{ab}}$ & $1.40 \pm 0.2^{\mathrm{a}}$ & $0.88 \pm 0.1^{\mathrm{b}}$ \\
\hline Triglycerides $\left(\mathrm{mg} \mathrm{dL}^{-1}\right)$ & $77.05 \pm 15.1^{\mathrm{a}}$ & $48.20 \pm 11.4^{\mathrm{bc}}$ & $32.33 \pm 10.0^{\mathrm{b}}$ & $51.04 \pm 13.0^{\mathrm{c}}$ \\
Cholesterol $\left(\mathrm{mg} \mathrm{dL}^{-1}\right)$ & $98.06 \pm 17.1^{\mathrm{b}}$ & $52.65 \pm 13.9^{\mathrm{c}}$ & $84.55 \pm 21.2^{\mathrm{bc}}$ & $176.94 \pm 36.5^{\mathrm{a}}$ \\
\hline
\end{tabular}




\section{DISCUSSION}

The water temperature, dissolved oxygen and $\mathrm{pH}$ of the experimental tanks did not show any variation and they were within the farming patterns for tropical fish. Tavares-Dias et al. (2010) reported a similar result from pirarucu farmed in a semi-intensive system.

The weight and length of the pirarucus did not change with use of different concentrations of MycosorbA $+{ }^{\oplus}$ in the diet. However, studies on other fish species using yeasts and the alga Chlorella sp. showed positive effects on both performance and hematological parameters (El-Boshy et al. 2010; Rahimmejad et al. 2016). Gibel carp (Carassius auratus gibelio) fed with diets that were supplemented with $0.8 \%$ to $1.2 \%$ Chlorella sp. showed significant increases in body weight, in comparison with the control group (Xu et al. 2014). On the other hand, the used of different yeast derivatives $(S$. cerevisiae) to supplement the diet of Nile tilapia did not achieve any significant results regarding growth (Pezzato et al. 2006). Likewise, Stara et al. (2014) evaluated different Chlorella sp. concentrations in diets for common carp (Cyprinus carpio L.) and did not observe any weight gain or growth.

In the present study, the fish did not attain a higher condition factor through incorporation of MycosorbA+ ${ }^{\oplus}$ in their diets in relation to the control. However, the pirarucus presented a good health condition during the experiment, which indicates that, apart from generally adequate environmental conditions, the supplementation did not have a noticeably deleterious effect on fingerlings during the test period. The condition factor is a quantitative indicator of the wellbeing of fish: it reflects recent food conditions and/or expenditure of reserves on cyclical activities that enable relationships with environmental conditions and the behavioral aspects of the species (Gomiero et al. 2008, 2010; Tavares-Dias et al. 2010, 2011; Silva et al. 2011). Intensive farming systems promote changes in water quality and stress due to handling, transportation and high stocking density. These factors modify the health condition of individual fish, reduce their immunity and make them more susceptible to parasites and infectious diseases (Chagas et al. 2009; OlivaTeles 2012). All these factors have negative impacts on fish welfare and performance, thus resulting in economic losses (Oliva-Teles 2012; Biller-Takahashi and Urbinati 2014).

The Ht and RBC levels of $A$. gigas fingerlings in this study were similar to those of fingerlings and juveniles analyzed by Drumond et al. (2010),. However, the Hb, MCV and MCHC measured in this study were higher than those of juveniles reported by Drumond et al. (2014). The supplementation with MycosorbA $+{ }^{\oplus}$ had generally no effect on red blood cell parameters, even in the concentration above the manufacturers reccommendation.
The lack of significant differences in leukocyte respiratory activity among control and treatments was probably related to the minimal changes in circulating leukocyte counts (Biller-Takahashi et al. 2013). Although the total leukocyte count in the pirarucus that received $0.2 \%$ MycosorbA $+{ }^{\oplus}$ was significantly lower than that of the control group, all groups tested in here had higher counts than those reported by Drumond et al. (2010), both in fingerling and in juvenile pirarucus. Leukocytes are the most important defense cells and are of great importance in assessments on fish immune systems (Tavares-Dias et al. 2007; Davis et al. 2008).

Few studies have evaluated the effects of nutrients on the function and proliferation of leucocytes in fish. Lymphocytes are the most abundant cells in the peripheral blood of fish and are involved in production of immunoglobulins and modulation of defense, and their proliferation stimulates fish immunity (Kiron et al. 2011). Neutrophils are primary phagocytes that proliferate in the circulation in response to infection, inflammation and stress (Drumond et al. 2010), and are considered to be the most important of the leukocyte immune defenses of pirarucus. Monocytes are the main phagocytes of fish, and they act in naturally or artificially induced infectious processes, and basophils are responsible for inflammatory reactions during the immune response (Ranzani-Paiva et al. 2013). Our results for lymphocyte, monocyte and neutrophil counts indicate that MycosorbA+ ${ }^{\circledR}$ does not seem to significantly stimulate nor depress these white blood cell types. The basophil count tended to be lower in the treatments in relation to the control, and was significantly lower in the intermediary treatment (M0,2\%), which may suggest a reduction in signs of infection.

Thrombocytes are organic defense cells (Tavares-Dias and Moraes 2004; Ranzani-Paiva et al. 2013) that act in relation to blood coagulation, phagocytosis and removal of cell debris (Ranzani-Paiva et al. 2013). Phagocytosis is considered to be a cellular response in which phagocytes can degrade microorganisms, pollutant particles and irritants (Rabinovitch 1995). Phagocytes are components of innate immunity (nonspecific) that are responsible for the primary response to pathogens and which coordinate the adaptive immune response, inflammation and repair (Geissmann et al. 2010). Thrombocyte counts tended to be higher in our treatments, specially in the lowest concentration of MycosorbA $+{ }^{\circledR}$, showing that its intake stimulated the production of these immune cells. Algae and yeast, which are present in MycosorbA $+^{\oplus}$, have many beneficial effects as dietary protein sources and have an immunostimulant effect for several species in aquaculture (Yu et al. 2016). The higher albumin concentration among the pirarucus fed with $0.2 \%$ MycosorbA $+{ }^{\oplus}$ may indicate an improvement in their immune system. For this reason, this concentration is probably the inclusion level that should be 
suggested for this species of fish, at this stage of development. The plasma total protein concentrations were higher in fish in the groups $\mathrm{M} 0 \%, \mathrm{M} 0.2 \%$ and $\mathrm{M} 0.4 \%$, and were accompanied by higher serum cholesterol levels. The plasma protein levels in this study were similar to those reported by Drumond et al. (2010), but with lower cholesterol levels. The latter authors also found that pirarucu fingerlings had naturally high cholesterol levels, compared with juveniles. The results from the present study were within the expected range for the species at this stage of life.

Gibel carp (C. auratus gibelio) that were fed with different concentrations of Chlorella sp. (0.4, 0.8, 1.2, 1.6 and 2.0\%) in their diet showed changes mainly relating to total protein and lipid metabolisms, as well as to immunity ( $\mathrm{Xu}$ et al. 2014). Even the carp that received the highest concentration of Chlorella sp. (2.0\%) showed a significant increase in plasma protein level, compared with the control group. However, unlike in the present study on pirarucus, Gibel carp showed lower cholesterol levels in the group with highest concentration of Chlorella sp. The higher plasma cholesterol levels observed in pirarucus that were fed with MycosorbA $+{ }^{\circ}$ at $0.4 \mathrm{~g} \cdot \mathrm{kg}^{-1}$ further indicates that this product seems to cause physiological alterations at higher concentrations and should not be used for pirarucus above $0.2 \mathrm{~g} \cdot \mathrm{kg}^{-1}$.

On the other hand, the incorporation of MycosorbA+ ${ }^{\circ}$ in the diet of pirarucu fingerlings seemed to contribute towards reducing their blood levels of triglycerids and glucose levels, with lowest levels observed in the two lower concentrations. Although the glucose concentration of the pirarucus in the control group was the highest among all groups in the present study, it was still below the average glucose values determined by Drumond et al. (2010) for fingerlings $\left(61.9 \pm 11.3 \mathrm{mg} \cdot \mathrm{dL}^{-1}\right)$ and juveniles $\left(48.5 \pm 16.6 \mathrm{mg} . \mathrm{dL}^{-1}\right)$.

\section{CONCLUSIONS}

This is the first study providing hematological-biochemical analyses on pirarucu that were fed with diets supplemented with MycosorbA+ ${ }^{\circ}$. At the two lowest concentrations tested $(0.1 \%$ and $0.2 \%)$ the product contributed towards increasing some defense cell counts and the albumin levels, without changes to hematological parameters, condition factor, and plasma cholesterol or triglyceride levels. Our results indicate that diets containing MycosorbA $+{ }^{\circ}$ in concentrations that are in accordance with the manufacturer's technical specification ( 0.5 to $2 \mathrm{~kg}$ of product per ton of feed) may be appropriate for diet supplementation of Arapaima gigas fingerlings. Additional studies are needed to assess the effectiveness of the product for eliminating mycotoxins from the diet of pirarucus.

\section{ACKNOWLEDGEMENTS}

This study was supported by the Brazilian Federal Agency for Support and Evaluation of Postgraduate Education (CAPES), through its Pro-Amazônia Program (\#230238.00754/2013-61). The authors thank the Brazilian Agricultural Research Corporation (Embrapa).

\section{REFERENCES}

Anater, A.; Manyes, L.; Meca, G.; Ferrer, E.; Luciano, F.B.; Pimpão, C.T.; Font, G. 2016. Mycotoxins and their consequences in aquaculture: A review. Aquaculture, 451: 1-10.

Association of Official Analytical Chemists (AOAC). 1995. Official Methods of Analysis, 16th ed. AOAC, Arlington, 1141p.

Araújo, C.S.O. De; Tavares-Dias, M.; Gomes, A.L.S.; Andrade, S.M.S.; Lemos, J.R.G.; Oliveira, A.T. De; et al. 2009. Infecçôes parasitárias e parâmetros sanguíneos em Arapaima gigas Schinz, 1822 (Arapaimidae) cultivados no estado do Amazonas, Brasil. In: Tavares-Dias, M. (Ed.). Manejo e Sanidade em Peixes de Cultivo. Embrapa Amapá, Macapá, Amapá. p.389-424.

Bairwa, M.K.; Jakhar, J.K.; Satyanarayana, Y.; Reddy, A. D. 2012. Animal and plant originated immunostimulants used in aquaculture. Journal of Natural Product and Plant Resources, 2: 397-400.

Bennett, J.W.; Klich, M. 2003. Mycotoxins. Clinical Microbiology Reviews, 16: 497-516.

Biller-Takahashi, J.D.; Takahashi, L.S.; Sailta, M.V.; Gimbo, R.Y.; Urbinati, E.C. 2013. Leukocytes respiratory burst activity as indicator of innate immunity of pacu Piaractus mesopotamicus. Brazilian Journal Biology, 73: 425-429.

Biller-Takahashi, J.D.; Urbinati, E.C. 2014. Fish Immunology. The modification and manipulation of the innate immune system: Brazilian studies. Anais da Academia Brasileira de Ciências, 86: 75-87.

Brandão, F.R.; Gomes, L.C.; Chagas, E.C. 2006. Respostas de estresse em pirarucu (Arapaima gigas) durante práticas de rotina em piscicultura. Acta Amazonica, 36: 349 -356.

Cavero, B.A.S.; Pereira-Filho, M.; Bordinhon, A.M.; Fonseca, F.A.L.; Ituassú, D.R.; Roubach, R.; et al. 2004. Tolerância de juvenis de pirarucu ao aumento da concentraçáo de amônia em ambiente confinado. Pesquisa Agropecuária Brasileira, 39: 513-516.

Chagas, E.C.; Pilarski, F.; Sakabe, R.; Massago, H.; Fabregat, T.E.H.P. 2009. Suplemento na dieta para manutenção da saúde de peixes. In: Tavares-Dias, M. 2009 (Ed.). Manejo e Sanidade em Peixes de Cultivo. Embrapa Amapá, Macapá, Amapá, p.132-225.

Cristea, V.; Antache, A.; Grecu, J.; Docan, A.; Dediu, L.; Mocanu, M. C. 2012. The Use Of Phytobiotics In Aquaculture. Lucrări Ştiințifice - Seria Zootehnie, 57: 250-255.

Davis, A.K.; Maney, D.L.; Maerz, J.C. 2008. The use of leukocytes profiles to measure stress in vertebrates: a review for ecologists. Functional Ecology, 22: 760-772.

Di Gregorio, M.C.; Neeff, D.V. de; Jager, A.V.; Corassin, C.H.; Carão, A.C. de P.; Albuquerque, R. de; Azevedo, A.C. de; Oliveira, C.A.F. 2014. Mineral adsorbents for prevention of mycotoxins in animal feeds. Toxins Reviews, 33: 125-135. 
Drumond, G.V.F.; Caixeiro, A.P.De.A.; Tavares-Dias, M.; Marcon, J.L.; Affonso, E.G. 2010. Características bioquímicas e hematológicas do pirarucu Arapaima gigas Schinz, 1822 (Arapaimidae) de cultivo semi-intensivo na Amazônia. Acta Amazonica, 40: 591-596.

El-Boshy, M.E.; El-Ashram, A.M.; Abdelhamid, F.M.; Gadalla, H.A. 2010. Immunomodulatory effect of dietary Saccharomyces cerevisae, $\beta$-glucan and laminariam in mercuric chloride treated Nile tilapia (Oreochromis niloticus) and experimentally infected with Aeromonas hydrophila. Fish \& Shellfish Immunology, 28: 802-808.

Geissmann, F.; Manz, M. G.; Jung, S.; Sieweke, M. H.; Merad, M.; Ley, K. 2010. Development of monocytes, macrophages and dendritic cells. Science, 327: 656-661.

Gomiero, L.M.; Junior, G.A.V.; Braga, F.M. de S. 2010. Relação peso-comprimento e fator de condição de Oligosarcusepsetus (Cuvier, 1829) no Parque Estadual da Serra do Mar - Núcleo Santa Virgínia, Mata Atlântica, Estado de São Paulo, Brasil. Biota Neotropical, 10: 101-105.

Gomiero, L.M.; Junior, G.A.V.; Naous, F. 2008. Relação pesocomprimento e fator de condição de Cichla kelberi (Perciformes, Cichlidae) introduzidos em um lago artificial no Sudeste brasileiro. Acta Scientiarum Biological Sciences, 30: 173-178.

IBGE. 2015. Produção da Pecuária Municipal 2014. Instituto Brasileiro de Geografia e Estatística. Rio de janeiro, Rio de Janeiro, Brasil. Produção da Pecuária Municipal, 42: 1-39.

Ishikawa, N.M.; Ranzani-Paiva, M.J.T.; Lombardi, J.V. 2008. Metodologia para quantificaçáo de leucócitos totais em peixe, Oreochromis niloticus. Archive Veterinary and Science, 13: 54-63.

Karthikeyan, V.; Selvakumar, P.; Gopalakrishnan, A. 2015. A novel report of fungal pathogen Aspergillus awamori causing black gill infection on Litopenaeus vannamei (pacific white shrimp). Aquaculture, 444: 36-40.

Kiron, V., Thawonsuwan, J., Panigrahi, A., Scharsack, J.P., Satoh, S., 2011. Antioxidant and immune defenses of rainbow trout (Oncorhynchus mykiss) offered plant oils differing in fatty acid profiles from early stages. Aquaculture Nutrition, 17: 130-140.

Le-Cren, E.D. 1951. The length-weight relationship and seasonal cycle in gonadal weight and condition in the perch (Perca fluviatilis). Journal of Animal Ecology, 20: 201-219.

Murjani, G. 2003. Chronic aflatoxicosis in fish and its relevance to human health. Central Institute of Freshwater Aquaculture, Bhubaneswar, India, 17p.

Oliva-Teles, A. 2012. Nutrition and health of aquaculture fish. Journal of Fish Diseases, 35: 83-108.

Pezzato, L.E.; Menezes, A.; Barros, M.M.; Guimarães, I.G.; Schich, D. 2006 Levedura em dietas para alevinos de Tilápia do Nilo. Veterinária e Zootecnia, 13: 84-94.

Rabinovitch, M. 1995. Professional and non-professional phagocytes: an introduction. Trends in Cell Biology, 5: 85-88.

Ranzani-Paiva, M.J.T.; Pádua, S.B.; Tavares-Dias, M.; Egami, M. I. 2013. Métodos para análises hematológicas em peixes. 1 ed., EDUEM, Maringá, 140p.

Roriz, B.C.; Santuci, M.A.; Garcia, R.G.; Mariano, W. dos S. 2015. Hipóxia e exposição ao ar como agentes estressores. In: Tavares-Dias, M.; Mariano, W. dos S. (Ed.). Aquicultura no
Brasil: Novas perspectivas. Editora Pedro \& João, São Carlos, São Paulo, p. 227-235.

Sahoo, P.K.; Kumari, J.; Mishra, B.K. 2005. Non-specific immune responses in juveniles of Indian major carps. Journal of Applied Ichthyology, 21: 151-155.

Sakai, M. 1999. Current research status of fish immunostimulants. Aquaculture, 172: 63-92.

SEBRAE. 2011. Manual de Boas Práticas de Produção do pirarucu em cativeiro. Serviço Brasileiro de Apoio às Micro e Pequenas Empresas-SEBRAE, Porto Velho, 46p.

Selim, K.M.; El-Hofy, H.; Khalil, R.H. 2014. The efficacy of three mycotoxin adsorbents to alleviate aflatoxin B1-induced toxicity in Oreochromis niloticus. Aquaculture International, 22: 523-540.

Siwicki, A.K.; Anderson, D.P.; Rumsey, G.L. 1994. Dietary intake of immunostimulants by rainbow trout affects non-specific and protection against furunculosis. Veterinary Immunology and Immunopathology, 41: 125-139.

Silva, A.M.O.; Tavares-Dias, M.; Jerônimo, G.T.; Martins, M.L. 2011. Parasite diversity in Oxydoras niger (Osteichthyes: Doradidae) from the basin of Solimóes River, Amazonas state, Brazil, and the relationship between monogenoidean and condition factor. Brazilian Journal of Biology, 71: 791-796.

Stara, A.; Sergejevova, M.; Kozak, P.; Masojidek, J.; Velisek, J.; Kouba, A. 2014. Resistance of common carp (Cyprinus carpio L.) to oxidative stress after chloramine- $T$ treatment is increased by microalgae carotenoid-rich diet. Neuroendocrinology Letters. 35: 71-80.

Tavares-Dias, M.; Araújo, C.S.O.; Gomes, A.L.S.; Andrade, S.M.S. 2010. Relaçáo peso-comprimento e fator de condição relativo (Kn) do pirarucu Arapaima gigas Schinz, 1822 (Arapaimidae) em cultivo semi-intensivo no Estado do Amazonas, Brasil. Revista Brasileira de Zoociências, 12: 59-65.

Tavares-Dias, M.; Barcellos, J.F.M.; Marcon, J.L; Menezes, G.C.; Ono, E.A.; Affonso, E.G. 2007. Hematological and biochemical parameters for the pirarucu Arapaima gigas Schinz, 1822 (Osteoglossiformes, Arapaimidae) in net cage culture. Electronic Journal of Ichthyology, 2: 61-68.

Tavares-Dias, M.; Monteiro, A.M.C.; Affonso, E.G.; Amaral, K.D.S. 2011. Weight-length relationship, condition factor and blood parameters of farmed Cichla temensis Humboldt, 1821 (Cichlidae) in central Amazon. Neotropical Ichthyology, 9: 113-119.

Xu, W.; Gao, Z.; Qi, Z.; Qiu, M.; Peng, J.; Shao, R. 2014. Effect of dietary Chlorella on the growth performance and physiological parameters of gibel carp, Carassius auratus gibelio. Turkish Journal of Fisheries and Aquatic Sciences, 14: 53-57.

Yu, Y.-Y.; Chen, W.-D.; Liu, Y.-J.; Niu, J.; Chen, M.; Tian, L.-X. 2016. Effect of different levels of Gracilaria lemaneiformis dry power on growth performance, hematological parameters and intestinal structure of juvenile Pacific white shrimp (Litopeaneus vannamei). Aquaculture, 450: 356-362.

Zar, J.H. 2010. Biostatistical analysis. 5th ed. New Jersey, PrenticeHall, 944p.

Received: 03/03/2017

Accepted: 17/03/2017 
